\title{
Neurofibromatosis type 1 (NF1) with vocal cord palsy: baffling presentation of a benign tumour
}

\author{
Chandrasekharan Rajasekharan, ${ }^{1}$ Varghese Thomas, ${ }^{2}$ Rajasekharan Parvathy, ${ }^{3}$ \\ Radhakrishnan Meera ${ }^{2}$
}

'Department of Internal Medicine, Medical College Hospital, Thiruvananthapuram, Kerala, India

${ }^{2}$ Department of Internal

Medicine, Government Medical College Hospital,

Thiruvananthapuram, Kerala, India

${ }^{3}$ Department of Internal Medicine, M.O.S.C. Medical College, Kolenchery,

Eranakulam, Kerala, India

\section{Correspondence to} Professor Chandrasekharan Rajasekharan,

drcrajasekharan@yahoo.com
To cite: Rajasekharan $C$, Thomas V, Parvathy R, et al. BMJ Case Rep Published online: [please include Day Month Year] doi:10.1136/ bcr-2013-009202

\section{DESCRIPTION}

A 33-year-old man presented with hoarseness of voice, cough and choking while eating for 1 week's duration. His sister was diagnosed with neurofibromatosis but was asymptomatic. Two years previously he had paraparesis due to a dumb-bell neurofibroma of the posterior mediastinum with intraspinal extension, which was excised with full recovery, but the lesion recurred and a re-excision was performed with histopathological confirmation as neurofibroma. On examination the patient was conscious with stable vitals. Multiple, extensive neurofibromas were seen on the face (figure 1A) and plexiform lesions over the trunk with scars of previous surgical incisions of biopsy (figure 1B). He had left vocal cord paralysis, confirmed by indirect laryngoscopy. Chest radiograph anteroposterior view showed a homogenous large mass with well-defined rounded margins in the upper left zone (figure 2A, arrow $1)$ displacing the trachea and the superior mediastinal structures to the right side (figure 2A, arrow 2) and elevation of the left dome of the diaphragm, suggesting left phrenic nerve involvement (figure 2A, arrow 3). The CT scan of the chest showed a soft tissue mass $12 \times 11.6 \times 10.6 \mathrm{~cm}$, displacement of arch of aorta thus compressing the recurrent laryngeal nerve (top arrow), and the trachea and oesophagus displaced to the right and anteriorly (upper arrow), and erosion of the left rib (bottom arrow). The patient was unwilling for surgery. We present an unusually large neurofibroma type 1 (NF1), which resulted in recurrent laryngeal nerve palsy.

NF1, also known as von Recklinghausen disease, is a rather common genetic disease, affecting approximately 1 in 3000 individuals. ${ }^{1}$ There is currently no cure for NF1 and surgical treatment is aimed at alleviating the symptoms that arise when NF tumours compress nearby bodily tissues, which can cause damage to those tissues or organs. ${ }^{1}$

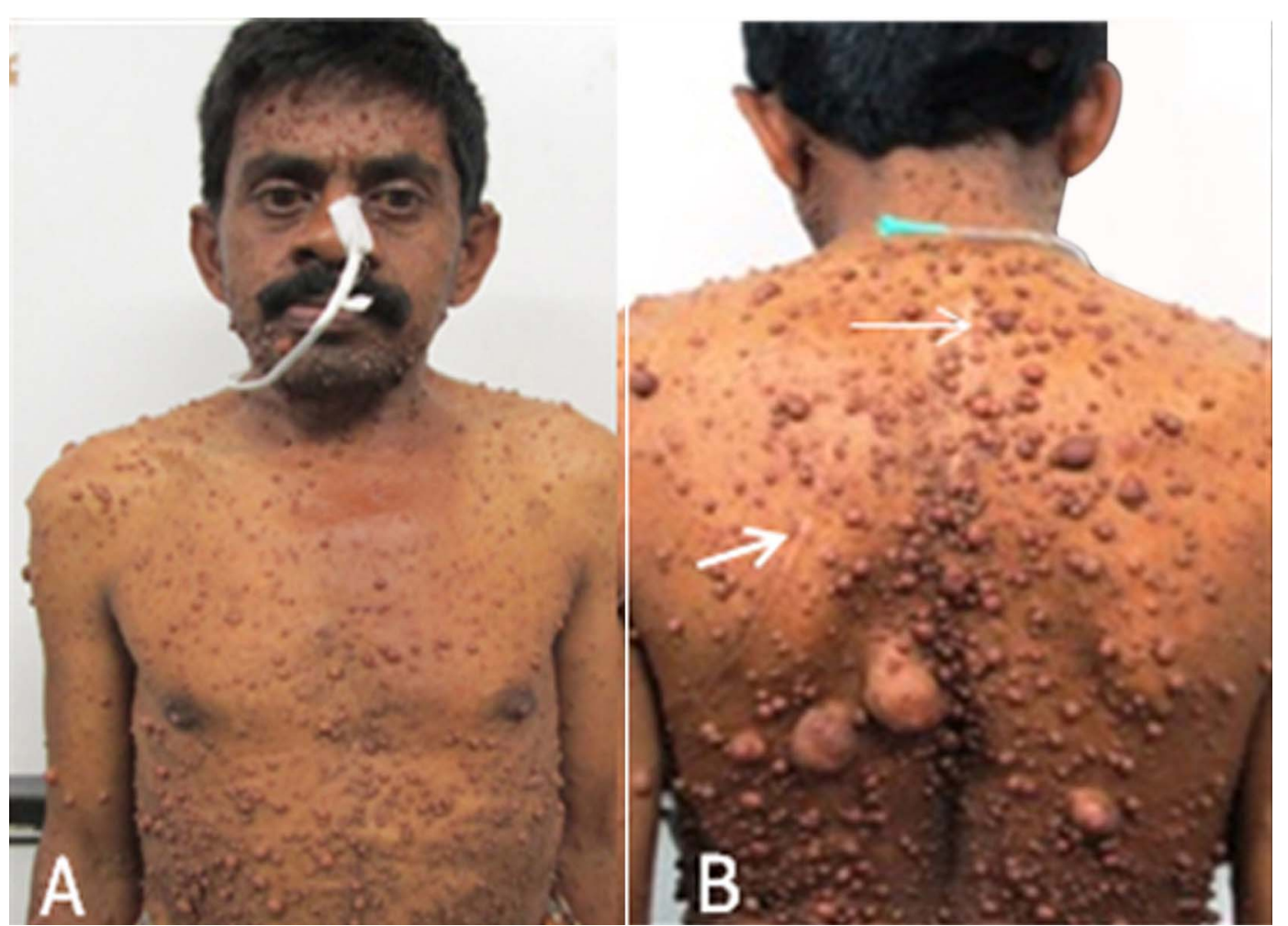

Figure 1 (A) Multiple, extensive neurofibromas were seen on the face with the nasogastric tube; (B) plexiform lesions over the trunk with scars of previous surgical incisions of previous biopsy. 


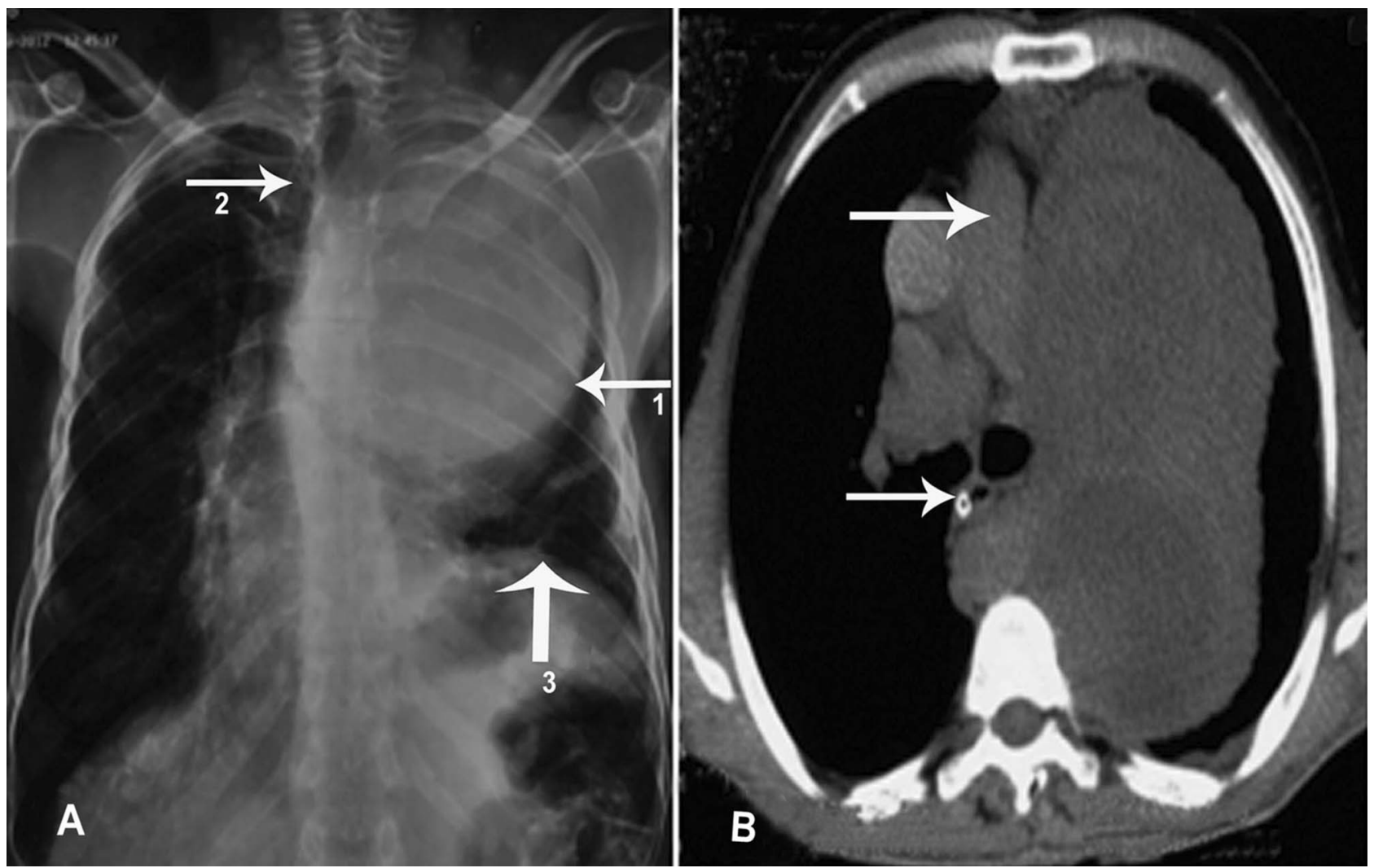

Figure 2 (A) Chest radiograph anteroposterior view showing a homogenous large mass with well-defined rounded margins in the upper left zone (arrow 1), displacing the trachea and the superior mediastinal structures to the right side (arrow 2), and elevation of the left dome of the diaphragm suggesting left phrenic nerve involvement (bottom arrow) and scoliosis (arrow 3) with scoliosis of the spine; (B) the CT scan of the chest showed a soft tissue mass $12 \times 11.6 \times 10.6 \mathrm{~cm}$, displacement of arch of aorta thus compressing the recurrent laryngeal nerve (upper arrow); (B) the trachea and oesophagus displaced to the right and anteriorly (bottom arrow).

\section{Learning points}

- Neurofibroma (NF) as a cause for recurrent laryngeal nerve paralysis is rare. ${ }^{2} 3$

- No known medical therapies are beneficial to patients with $\mathrm{NF1}{ }^{4}$

- To prevent local recurrence, wide en bloc resection is the treatment of choice. ${ }^{5}$

- Surgical intervention may not guarantee a complete resection of the tumour, but it may serve a palliative function. ${ }^{1}$

- If the patients elect not to attend a specialist NF1 clinic, they should be fully conversant with the problems that they might encounter. ${ }^{6}$

Contributors RC was the primary clinician under whom the patient was admitted investigated and treated. TV, MS, PR were the residents and final year electives in charge of the case. All the authors had an equal role in writing, editing and formatting the manuscript and also in following up the patient.

Competing interests None.

Patient consent Obtained.

Provenance and peer review Not commissioned; externally peer reviewed.

\section{REFERENCES}

1 Torpy JM, Burke AE, Glass RM. Neurofibromatosis. JAMA 2009;302:2170.

2 Smahi M, Lakranb M, Ouadnouni $Y$, et al. Intrathoracic phrenic nerve neurofibroma. Ann Thorac Surg 2011;91:e57-8.

3 Tanaka $\mathrm{H}$, luchi $\mathrm{K}$, Mori T, et al. A case of schwannoma of intrathoracic right phrenic nerve. Nihon Kyobu Geka Gakkai Zasshi 1995;43:380-3.

4 Karwacki MW, Woźniak W. Neurofibromatosis—an inborn genetic disorder with susceptibility to neoplasia. Med Wieku Rozwoj 2006;10(3 Pt 2):923-48.

5 Jones A. Primary and metastatic tumors of the spine in Introduction to Spine Surgery: essentials for ORP, fellows, and residents (AO Spine International Series). 1st edn. Switzerland: AO publishing, 2006(2.5):120.

6 Ferner RE, Huson SM, Thomas N, et al. Guidelines for the diagnosis and management of individuals with neurofibromatosis 1. J Med Genet 2007;44:81-8. 
Copyright 2013 BMJ Publishing Group. All rights reserved. For permission to reuse any of this content visit http://group.bmj.com/group/rights-licensing/permissions.

BMJ Case Report Fellows may re-use this article for personal use and teaching without any further permission.

Become a Fellow of BMJ Case Reports today and you can:

- Submit as many cases as you like

- Enjoy fast sympathetic peer review and rapid publication of accepted articles

- Access all the published articles

- Re-use any of the published material for personal use and teaching without further permission

For information on Institutional Fellowships contact consortiasales@bmjgroup.com

Visit casereports.bmj.com for more articles like this and to become a Fellow 